\title{
Opposition in the Language of Representation and Undecidability of Pronouns in William Shakespeare's Sonnets
}

\author{
Parisa Hamidizadeh ${ }^{1}$, Yazdan Mahmoudi* \\ ${ }^{1}$ Department of English and Literature, College of Art and Social Science, Osmania University, Hyderabad, India \\ ${ }^{2}$ Department of English Literature, Shahid Beheshti University, Tehran, Iran
}

Corresponding Author: Yazdan Mahmoudi, E-mail: yazdan_mahmoodi@yahoo.com

\section{ARTICLE INFO}

\section{Article history}

Received: September 08, 2017

Accepted: October 29, 2017

Published: December 30, 2017

Volume: 8 Issue: 6

Advance access: December 2017

Conflicts of interest: None

Funding: None

\section{Key words:}

Shakespeare,

Undecidability,

Sonnet,

Pronoun,

Opposition

\begin{abstract}
The purpose of this study is to consider the undecidability of pronouns in William Shakespeare's sonnet sequence. In sonnet 53 of Shakespeare's sonnet sequence it is not clear that whether the beloved is male or female, because the beloved has affinity to both men and women: "And you, but one, can every shadow lend/Describe Adonis, and the counterfeit/Is poorly imitated after you/On Helen's cheek all art of beauty set" (53. 4-7). In fact, in sonnet 53 the beloved has been likened both to Adonis who is a male character and to Helen that is female. Therefore, the speaker of sonnets uses pronouns in a very confusing manner that causes confusion for the reader in differentiating between male and female pronouns, because in some sonnets a reversal takes place in the reference point of the pronouns. Even in some of these sonnets it is never clear whether the pronoun "he" refers to a male subject or object, or whether the pronoun "she" is referring to male object. Important examples of this claim are sonnets 20 and 127. In sonnet 20 , for example, the speaker tells the addressee that “A woman's face with nature's own hand painted/Hast thou, the master mistress of my passion/A woman's gentle heart, but not acquainted/ With shifting change, as is false women's fashion" (20.1-4).
\end{abstract}

\section{INTRODUCTION}

The speaker attributes not only female characteristics such as beauty and delicacy to his loving friend but also regards his friend to be superior of women for his purity of heart. Indeed, the addressee, a male object, is considered as "not she" (Smith 420). In fact, this process creates a psychological depth as well. At the very beginning of the Dark Lady sonnets, we have the same problem in sonnet 127 , where he never represents the lady by the means she could be represented: (127.7-8). Therefore, the dark lady is not pictured as who she is but as who she is not. Of course, the formal value of this challenge and undecidability can be aesthetic pleasure for the reader.

In this respect, it is of high significance to note that the problem of confusion of distinguishing between pronouns can also be attributed to the speaker, because there is little evidence whether the speaker is male or not. It is possible that the unique "I" of the sonnets is a split "I" that gives them a male or female identity.

In the second part of the sequence, there is an opposition in the language of representation in which two things that are, for example, not comparable are compared to create a kind of replacement. In fact, two opposite features are represented by substitution or combination.

\section{YOUNG MAN SONNETS: THE METAPHOR OF BEAUTY AND ETERNALITY}

The first 126 are dedicated to a "fair" young friend whom the speaker of the sonnets urges him to get marry and transmit his beauty to posterity. Indeed, these sonnets demonstrate the transcendental love and vehement feelings of the narrator toward the addressee. The interesting point is that the speaker of the sonnets represents the young man by means of a certain figurative language. The speaker uses certain metaphors, especially in the first 20 sonnets, to represent the young man's excellence that is in an opposition in the way he describes the Dark Lady. The speaker constantly praises young man's beauty in many lines: "Where all the treasure of thy lusty days/How much more praise deserved thy beauty's use." (2.6-9). Bell believes that "The sonnets as a whole are usually read as a morality play in which the young man plays "the better angel," the idealized spirit of male friendship (heightened by the sexual frisson of 20), while the dark lady plays "the worser spirit" (293). In sonnet number 4 the speaker uses the metaphor of legacy and tells him that you should not waste the precious legacy of youth: "Unthrifty loveliness, why dost thou spend/Upon thyself thy beauty's legacy?" (4.1-2). Later he extends the metaphor of beauty to 
warn his friend not to waste his time and beget a child. Those hours that with gentle work did frame/The lovely gaze where every eye doth dwell/Will play the tyrants to the very same/ And that unfair which fairly doth excel" (5.1-4). The literary critic Duncan-Jones believes that in this sonnet "however, deploying a metaphor which readers of Sidney's New Arcadia will recognize as symbolizing marriage, the speaker tells him that he can preserve the essence of his beauty, even as Elizabethan housewives preserve roses by distilling rose-water" (120). He urges the young man to marry and transmit his beauty to posterity by begetting a child and make others happy "Make sweet some vial, treasure thou some place" (6.3).

Perhaps the climax of the metaphor of beauty in procreation sonnets is sonnet 7 in which the speaker symbolizes his love to the sun that is in height "Lo, in the Orient when the gracious light/Lifts up his burning head, each under eye/ Doth homage to his new appearing sight/Serving with looks his sacred majesty" (7.1-4). Throughout sonnet 16 the speaker says that his poetry cannot really show his beauty and virtuous nature and likens the addressee to "flowers": "With means more blessed than $\mathrm{m}$ y barren rhyme?/Now stand you on the top of happy hours/And many maiden gardens, yet unset/With virtuous wish would bear your living flowers" (16.4-7). In the extension of the metaphor of beauty, the speaker in the famous sonnet 18 says that his loving friend is more beautiful than a lovely summer day: "Shall I compare thee to a summer's day?/Thou art more lovely and more temperate" (18.1-2). Further he says that even the death cannot defeat him and he will be eternal in his poetry. In sonnet 20 the speaker portrays the young man as an ideal beauty who surpasses all women in beauty and even nature is jealous of. In this sonnet a lot of female feature are attributed to the addressee: "A woman's face with nature's own hand painted/ Hast thou, the master mistress of $\mathrm{m} y$ passion/A woman's gentle heart, but not acquainted/With shifting change, as is false women's fashion" (20.1-4).

\section{DARK LADY SONNETS: A REVULSIVE VIEW}

The major difference in the representation of the Dark Lady from those of the fair man lies in the way that he shows his love to her. The reason is that, as opposed to his love toward the young man, the speaker prefers to have a lovely physical relation with the lady. This implies the fact that he merely looks at the lady not only as inferior to men but also as an object or instrument to satisfy his lustful desire. Indeed, in the last 28 poems the speaker uses some scornful metaphors to represent the lady. Although in some sonnets the speaker praises the dark complexion of the lady, in the latter sonnets he attributed the dark color to the ill behavior of the lady in a contemptuous manner: "In nothing art thou black save in thy deeds/And thence this slander, as I think, proceeds" (131.13-14). Extending the metaphor of darkness in the behavior of the lady, the speaker describes the selfishness of the lady as being scornful to him. He says the cruel beloved's eyes mourn for him as the lover: "To mourn for me, since mourning doth thee grace/And suit thy pity like in every part/ Then will I swear beauty herself is black/And all they foul that thy complexion lack" (132.11-14). In the next poem the speaker complains that the dark lady not only has enslaved him but she also has imprisoned his friend by her cruel eyes, so he asks her to set free his friend: "Beshrew that heart that makes $\mathrm{m}$ y heart to groan/For that deep wound it gives $\mathrm{m} y$ friend and me" (132.1-2). In sonnet 137 the speaker believes that his eye have made a terrible mistake to have fallen in love with the dark lady. Therefore, he asserts that she is not virtuous and decent anymore. But the paradoxical point is that the speaker is still in love with her: "T h o u blind fool love, what dost thou to mine eyes/That they behold, and see not what they see?" (137.1-2). The speaker elaborates the theme of the previous sonnets that she is not made of truth. He keeps on that the lady has been unfaithful with him and continues to talk to her by an insulting language: "O call not me to justify the wrong/That thy unkindness lays upon my heart/Wound me not with thine eye, but with thy tongue" (139.1-3). In sonnet 144 the speaker speaks of two loves, the dark lady and his young friend. He accuses the lady of wronging his male friend and is resented unless his "angel" turn into a "devil": "The better angel is a man right fair/The worser spirit a woman coloured ill" (144.3-4). Duncan-Jones believes that "The sonnet's number in the sequence, $12 \times 12$, known as a 'gross', may be especially appropriate to this enumeration of the speaker's amorous possessions, which prove to be 'gross' also in the sexual sense" (402).

To be more precise of what I mean by the idealized and non-idealized depictions of the young man and the dark lady, in the following table we quote Ahmad Zadeh's lecture about the sonnets' binaries on Shakespeare's $400^{\text {th }}$ Commemoration:

Following our structuralist approach towards the sonnets, by reference to Bruce Smith, it is interesting to take a look at sonnets 20 and 127 based on the approach of the famous structuralist critic Greimas and his theory; that is, semiotic square which will support the aforementioned theory of the sonnets.

Perhaps we can say that sonnets 20 and 127 are two of best examples in the Shakespeare's sonnet sequence that question the reference points or the addresses the speaker refers to. Indeed, it is never obvious that to whom the speaker of these two sonnets is referring to, a man or a woman. So, there is some sort of ambiguity in identifying the gender of the addressee in these sonnets. The main problem is that sonnet 20 is one of the "Fair Youth" sonnets but has many references to feminine qualities as if the addressee were female. The same ambiguity can be traced in sonnet 127 which is the first of the "Dark Lady" sonnets. In fact, the lady is represented not by her own qualities but by the qualities that she does not possess. In this respect, there is some kind of hierarchy and binary in the male/female description of the addresses that makes these sonnets a fertile ground for structuralist analyses especially the structuralist theory of Algirdas Greimas whose Semiotic Square provides us with a possibility for expanding binaries from two to four opposing concepts.

To be more specific, Semiotic Square entails two binaries of opposition and negation. For example, masculine and feminine are in opposition but masculine and not-masculine are in negation not in opposition. The same theory is 


\begin{tabular}{|l|l|}
\hline Young Man Sonnets: An Idealized Depiction & Dark Lady Sonnets: "The Worser Spirit" \\
1. Blond beauty & 1. Black beauty \\
2. Emblematic or idealistic depiction & 2. Using an ordinary language \\
3. Emblem of virtue & 3. An ugly and false view \\
4. Using the pronoun "you" for him that embodies closeness & 4. Using the pronoun "thou" that embodies distance \\
5. Immorality through procreation & 5. Death \\
6. Passive object of desire & 6. Active object of desire \\
7. Paternal role metaphors & 7. Maternal role metaphors \\
8. A sacred character & 8. Lust and lustfulness \\
9. Nature & 9. Culture \\
10. A praising tone & 10. A mocking tone \\
11. There is hierarchy and he is of a high position & 11. There is sameness \\
12. The same gender /race, different class & 12. Different gender/race, the same class \\
13. Lacanian Imaginary Order that embodies a sense of unity & 13. Symbolic order \\
14. The Self & 14. The other \\
15. Emphasis on eye & 15. Implying blindness \\
16. Revising memory & 16. Loss \\
17. Self-embellishment & 17. Self-denial \\
18. Lack of fulfillment of the speaker's desire & 18. Fulfillment \\
19. He as not-she & 19. She as not-she \\
20. Based on Petrarchan tradition & 20. Anti-petrarchan tradition \\
\hline
\end{tabular}

applicable to Shakespeare's sonnets 20 and 127 because both of them contain opposing and negating binaries.

Sonnet 20 is known to be addressed to a male friend whom the speaker of the sonnet asks him to marry and beget a child to transmit his beauty to the posterity. But this sonnet attributes female beauty to the addressee as if nature herself painted the face of the loving friend "A woman's face with nature's own hand painted". Here the fair friend is described no only as being very delicate, "gentle heart" and possessing "women's soul" but also is represented to be superior to women because of his purity of heart. In fact, nature wanted to make a perfect model but for she was jealous, she made "addition me of thee defeated". Therefore, it can be asserted that there not only opposition but also negation of each binary. The following square can illustrate how he/she binary are both in opposition and in negation of each other:
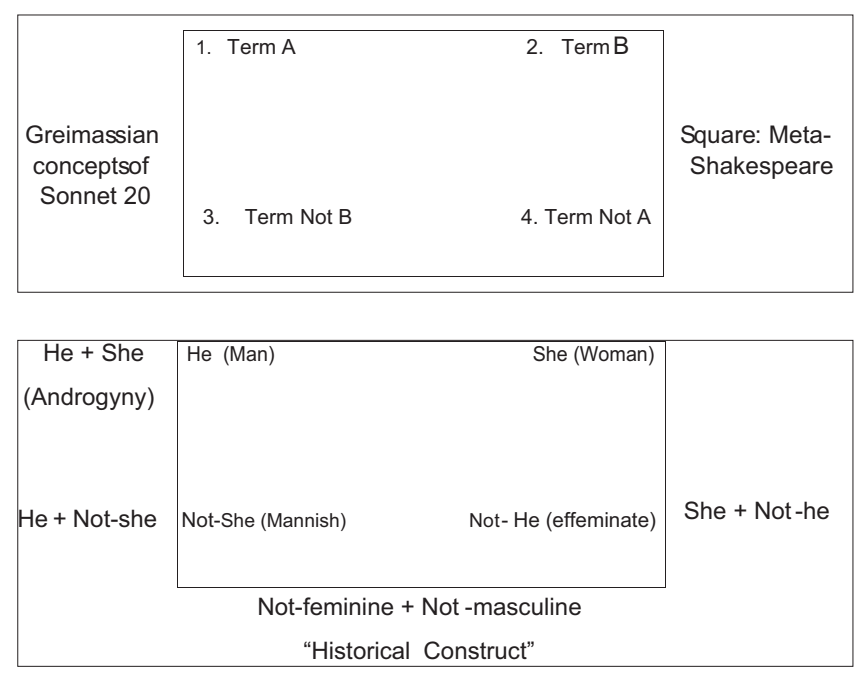

Therefore, the addressee is he but is taken into consideration as not she, so he is not she. The reason for this idea can be the patriarchal views of the speaker, for the man is superior to all women. Here, "he" and "she" in opposition but "he" and "not-she" and "she" and "not-he" negate each other "A man in hue, all hues in his controlling/Which steals men's eyes and women's souls amazeth" (20.7-8). But literary critics such as Bruce Smith place the addressee of the sonnet in a not-feminine and not-masculine position. In other words, Smith believes that "he" and "she" in these sonnets are social and historical constructs that do not refer to actual characters. Smith's idea perfectly has its position in Greimas's square. Greimas defines some more classes as meta-terms, such as the combination of masculine and feminine and not-masculine and not-feminine that, of course, have no actual equivalence in the real world; also Smith rejects the actuality of the sonnets' characters.

The same semiotic square can be applied to sonnet 127 as well. As in sonnet 20, we see a reversal in the reference point of the sonnet 127. In fact, none of addressees of these two sonnets are represented by the means they could be represented. The addressee of sonnet 127 , that is apparently a dark lady, is not defined as "she" but is represented as "not-he". In this sense, the superiority of man over woman is repeated here as in sonnet 20 for the addressee of sonnet 127 is defined not based on her possessions but according to what she does not possess. The following square shows the position of she/he pronouns in sonnet 127 :

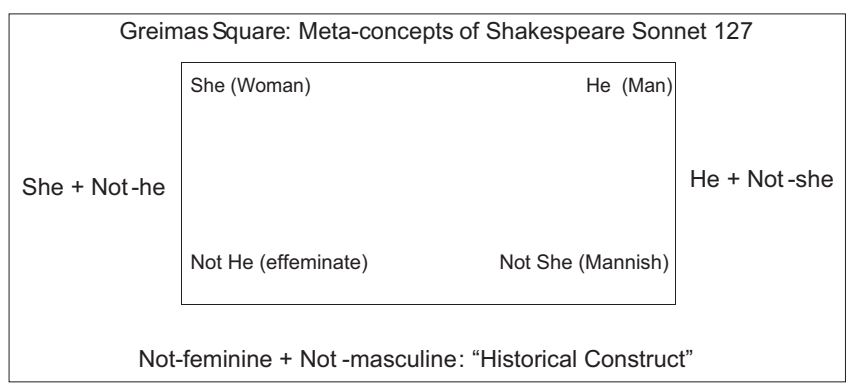




\section{CONCLUSION}

In sum, according to these two sharp categories or binary metaphors that the speaker of the sonnets uses to represent both the Young Man and the Dark Lady, we can say that the sonnets revolve around an ideal representation of the Young Man and a non-idealistic representation of the Dark Lady. The speaker applies many praising metaphors in the description of his loving friend while uses negative associations for representing the dark lady. The reason behind this lies in some major binaries which underlie the whole sonnets. These binaries are man/woman, white/black, love/hate, and spiritual love vs. physical love. In Young Man sonnets there is going to be a unification between the self and the other while in Dark Lady sonnets revulsion and separation are emphasized. In the first part we see that there is a lack and the speaker does not achieve union, but in the second part there is a fulfilment. In the first part the speaker always associates his beloved with beautiful metaphors, while in the second part the beloved is displaced by revulsive images. For example in 127 he says something in one line but he denies it in another "desire lost in action."

The expression of desire is very different in the first part of the sequence, because the argument is based on a paradox and desire is loss and in the second part this is repeated. In a Lacanian sense desire comes from loss and loss comes from desire. The binary of man/woman is highly suggestive because of some reasons. To discuss in terms of hierarchy, the speaker firstly tells of his love toward the young man. Also he dedicates 126 out of 154 sonnets to his male friend. Another significant binary in this respect is fair/dark binary in which the speaker never criticizes the young man for being fair, but, in the last sonnets, he associates her dark complexion with ill behavior. Moreover, his love toward his loving friend, while his love of the lady turns into anger suddenly.
At the end, the speaker's love of the young man can be considered as Platonic and spiritual, but his desire for the lady is mainly for the sake of sexual relationships. The important point is that these binaries leads to another binary which the speaker in some of the sonnets is entangled in, i.e. reality vs. appearance. The speaker in the course of the sonnets is not certain about what is true and what is not. This opposition can be fully traced in sonnets 137-139. The true/ false binary can be related to the ideal and non-idealistic representation of his two loves, because the speaker assumes the young man's notable characteristics to be actual but those of the dark lady no more than a disguised illusion. In the case of the problematic pronouns I should mention that some of the sonnets are not associated by any male or female pronoun.

Therefore, it can be noted that sonnets such as number 94 may refer something other than love relation. At the end, it is never clear whether the sonnets are addressed to a man or a woman. We doubt whether the speaker is even male or female. Of course, this premise may reverse all we have thought about the sexuality of the addresses.

\section{REFERENCES}

Ahmad Zadeh, Shideh. "Shakespeare's $400^{\text {th }}$ Commemoration." Shahre Ketab, Tehran. 23 April 2016. Lecture.

Bell, Ilona. "Rethinking Shakespeare's Dark Lady." A Companion to Shakespeare's Sonnets. Ed Michael Schoenfeldt. London: Blackwell, 2007: 293-313.

Duncan-Jones, Katherine. Shakespeare's Sonnets. London: AS, 1998.

Smith, Bruce, R. "I, You, He, She, and We: On the Sexual Politics of Shakespeare's Sonnets." In Shakespeare's Sonnets: Critical Essays, ed. James Schiffer. New York, Garland. Rpt. London: Routledge, 2000. 